\title{
Once a Slave..., Not Always a Slave: Acquiring Freedom on São Tomé Island
}

\author{
Robert Garfield \\ Department of History, College of Liberal Arts and Social Sciences, DePaul University, Chicago, Illinois, USA
}

Copyright $\mathrm{C} 2018$ by authors, all rights reserved. Authors agree that this article remains permanently open access under the terms of the Creative Commons Attribution License 4.0 International License

\begin{abstract}
The island of São Tomé, located off the west-central coast of Africa, became a template for slave-based sugar islands elsewhere in Africa and in the West Indies. The common assumption is that slaves, taken to the island from the nearby African mainland, remained so forever, as did their descendants. In fact, many slaves won their freedom, through manumission, purchase, royal proclamation and, especially, rebellion. By the mid- $16^{\text {th }}$ Century, ex-slaves and their descendants actually ruled the island, both economically and politically, even though slavery still remained the basis of the island's economy and social structure. This paper looks at the origins and evolution of São Toméan society, noting the ways in which enslavement could be overcome or ended, and what the practical effects of this were for the island's social, economic, and political future. It reviews the many violent rebellions produced by the slave system and how these altered the lives of those who still remained enslaved.
\end{abstract}

Keywords São Tomé, Slavery, Rebellion, Social Structure, Sugar

\section{Introduction}

How one acquired slave status in pre-modern Africa is by now a truism: get captured in war; be condemned for a crime; fail to pay off a debt. Less well studied is how one loses slave status. Just how do people who by definition have no rights, power, authority or freedom acquire such things, or at least the ability to seek them? The history of São Tomé may serve to illustrate this other side of the slave system.

\section{Settlement}

The island of São Tomé lies in the Gulf of Guinea some one hundred miles west of the African mainland of Cape Lopez (Gabon). The total area is some 325 square miles
(850 square kilometers). The geography of São Tomé served to confine European settlement to the north, leaving the mountainous south largely untouched save as a refuge for those who did not or would not fit into the social or political regime that held sway in the northern flatlands.

São Tomé was the first of the islands of the Gulf of Guinea to be found by Europeans, discovered on 21 December 1470 -- St. Thomas' Day -- after whom, in keeping with Portuguese tradition, the island was named. [1] Most importantly, the island was uninhabited. [2] The lack of population, the fertility and presumed healthiness, all disposed King João II to see São Tomé as a site for an extensive settlement. In addition, São Tomé resembled in size, position vis-à-vis the mainland and lack of native population, Madeira and the Cape Verde Islands, where plantation settlements using slave labor from Africa had already been made with great success. [3] That São Tomé was also perfectly situated to become the focus of the slave trade from the Kingdom of Kongo (modern northwestern Angola) to Elmina (on the Gold Coast, modern Ghana) and Brazil, was wholly fortuitous, though historically significant.

To settle the island, the King had recourse to the Donatária or Doação, the granting of the island to a favorite to rule as a personal holding, subject to the legal restrictions and financial benefit of the Crown; it was a system already used in the Azores and Cape Verde islands as well as in Madeira. Slavery was foreseen early, as indicated by the various regulations made for the island, which were to apply to all persons regardless of "natureza (status) or quality." The rights and privileges of the settlers were laid down in a decree of December, 1485, which granted the São Toméans the right, inter alia, to trade for slaves. The expenses of the island's government were to be met by the Donitário, who was to receive for the purpose one braço ("arm," but here meaning a slave) each year for every engenho (mill) built in the island. The directive illustrates the recognition, even before actual settlement had begun, that São Tomé would be a slave-based society.

The island's role as a sugar producer was also provided for. The same decree provided that of every 100 arrobas (at 
thirty-two pounds per arroba) of sugar grown, seventy-five arrobas were for the grower, while the income of fifteen were reserved for the crown and ten for the Church. Though it was intended that the first settlers should cultivate sugar cane, among other crops, there is no record of their having done so, due to the lack of population.

To meet the latter need, the Donitário was given the right to seize and carry to São Tomé dégrédados, criminals condemned to jail or exile for various crimes. [4] Press gangs were used to get laborers: criminals, prostitutes, and others among Lisbon's undesirables. But more population was needed, people who could lend some stability to the society and also provide cheap and more or less willing labor. This was provided by the co-option of yet another group in Portugal, the children of refugee Jews.

These Jews included many who had recently arrived from Castile, fleeing from the Christians who were in the process of reconquering Granada, the last Iberian Moorish kingdom. Their large numbers led the King to order that the refugees go elsewhere within four months or face arrest or expulsion, either of which could lead to an encounter with the Inquisition, either in Portugal or back in Castile. Portugal at this time had nearly 100,000 native Jews in a population of a little over one million, and their numbers, combined with that of the Castilians, were assumed to be a threat to Portugal's Catholicity. [5]

At this point, it was suggested to the royal council that the King could rid his country of Jews, perform a major service for the Faith, and help the struggling colony of São Tomé by taking the youngest children of the Jews, baptizing them, and sending them to the island, where they would provide an immediate younger generation and some social stability in a society that would otherwise consist of only the dregs of Lisbon. The children were seized, instructed in their new faith, and presented to families, or at least to a man and woman who were to live together, and sent with the rest of the colonists to the island. Eventually, many of them, or their descendants, became some of the wealthiest and most powerful men on the island.

The need for labor was taken care by the use of African slaves. Those brought to the island, like most of the others taken by the Portuguese in the 16th century, came from the Kingdom of Kongo, with which they had established contact at about the same time that São Tomé was discovered. Female, as well as male, slaves were brought to the island for the specific purpose of providing "a black of the opposite sex" for every white colonist. It was simply a matter of populating the island as quickly as possible, and for those who accepted one of these human gifts, actual marriage was optional. Female "breeding stock" was provided for the male slaves, as well as for the white settlers of the island. [6] This government-sponsored miscegenation illustrates, along with the emptying of the jails of Lisbon, the difficulty of populating the island, and the lengths the Crown would go to in order to get it settled and producing revenue for the Fazenda Real, or royal treasury. But in its haste, the Crown sowed the seeds of later social and racial conflict.

The King gave the donitário full power over the new colony, his authority running to all matters involving "Moors, Negroes, Whites, Freemen, and Captives," an interesting classification of the future population. [7] In addition, the colonists were given the right to trade in all the islands of the Gulf of Guinea, on the Cameroon coast and in Kongo, the trade in the latter being solely in slaves.

In 1493, a permanent settlement was established and the cultivation of sugar, wheat and grapevines begun. By 1499 , a number of fazendas (plantations) had already been established on the island, their existence indicating that slaves had already been imported. The actual number of slaves carried to the island in the five years 1494-1499 was about 930 , of which 150 died. Some slaves had already been sent to Elmina; thirty is the number that was entered in the records. Thus, within a half-decade of its foundation, São Toméan society had begun to flourish economically and was already dependent, internally and externally, on slaving.

\section{Social Beginnings}

A new donatário of the island Fernão de Mello, Alcaide-Mór (mayor) of the city of Évora, was chosen in 1499. [8] The racial beginnings of São Toméan society can be seen in the decrees describing his rights and jurisdictions. In noting the persons over whom he was to rule, the Crown extended de Mello's authority to "escravos, negros, e brancos que houves na dita ilha" -- "slaves, negroes, and whites who are on the island." He was further granted control over all "captivos e forros," captives and freemen. [9]

Interestingly, even at this early date, slaves are seen as a separate category from "blacks." Also, the reference to "negros," when the usual term was preto, "black," suggests that a separate class of Africans, or African-descended persons, already existed on the island, and were sufficiently differentiated to warrant a special designation. Further, the division between "captives" and "freemen" would indicate that both classes of bondsmen, dégrédados and African slaves, were losing members into the "free" category. Possibly, some of the freemen were children of the black-white liaisons encouraged by the Crown, though it would be rather early for such offspring to be of an age to claim such a status. Nevertheless, the racial/social division of the island's populace had already begun.

Most likely, many of the dégrédados and slaves had acquired property and/or wealth through trade, and had purchased their freedom, though there was no legal provision for doing so. The most reasonable means for acquiring such freedom would be that the black concubine of a white of either sex would seek, or be given, equality of treatment and status by his or her partner. Since many of 
the dégrédados had already been released from their status because of their conduct (and because the high death-rate made the utilization of all possible man- and woman-power a necessity) it would not be difficult for them to assume the same social and legal position as the original freemen and then to insist on their mates sharing that status. The dates of the original references, 1499-1500, show that such divisions in the society, and the social evolution that caused them, appeared very early in São Tomé's history. It should be noted that the newly created freemen were not fully accepted by their nominal legal superiors and it would take violence and eventually royal intervention to secure their rights.

The best description of São Tomé in the first years of the 16th Century is given in the Descrição of Valentim Fernandez, written sometime after 1510. [10] His figure for the total population, 1,000, whom he referred to as "inhabitants," is clearly a reference to whites only; he did not mention or suggest that existence of a free non-white class, though he noted the past policy of miscegenation. As for slaves, he said, there were at the time some 2,000 laboring on the island itself, while some five to six thousand were held for export. [11] Whites earlier deported from Portugal had in many cases become moderately large slave-owners, owning fourteen or more slaves, whose principal task was to plant and harvest food crops, such as yams (from Africa) or maize (later introduced from the New World). [12]

Though there is little record of social agitation in the early years of the de Mello regime, it must have existed -not among slaves, but among those who had been taken as concubines, and their children, many of whom had now grown up and who were not happy at the continued discrimination against them. Their complaints may be judged from the petition of one Alfonso Gil, who pleaded with King Manuel I (1495-1521) for release from illegal imprisonment. Gil claimed that he was a free man, being descended from a union of a Portuguese and an African concubine. However, he had been arrested and treated as if he were a slave, he complained; whatever the merits of the charges against him, he wanted the benefits of law that were the right of all free Portuguese subjects.

Replying to Gil's request, the King took note of the many slaves brought to the island in the time of his uncle, King João II (1481-1495), and of the fact that they were not brought to the island to labor (as slaves) but to populate the island. Seeing Gil's treatment as an injustice, the King decreed on 29 January 1515 that all females brought to São Tomé for purposes of breeding, as well as all their filhos (literally "sons," though it can also mean all children) were to be considered forros (freemen). As long as they behaved properly, they were never to be constrained, "degraded" or re-enslaved. This was not to apply, however, to slaves taken to São Tomé specifically for labor on the island's plantations or for later export. The need for, and the terms of, the King's decree[13] strongly suggest that the forros had indeed assumed or had been given such freedom before but had had their status challenged, perhaps by some fazendéiro who needed slaves or by some official who found that ancestry was a sufficient excuse to eliminate someone who had incurred his displeasure.

The forros, then, were seen both by the white São Toméans and by the authorities in Lisbon as a distinct legal class, requiring special guarantees of their freedom. The ruling group on São Tomé, nevertheless, did not accept the King's decision with good grace. It would have been easy after the first decree simply to accept all such persons as freemen, but it took a second royal proclamation, in January $1517,[14]$ to extend the freemen's status to all males, and to any others who were not covered by the decree of 1515. To compensate their former masters, the King provided for the distribution of esmollas (aid) to the masters and to the new freemen as well, to assist their transition to freedom, which would require the purchase of some land or a trade license.

The fact that esmollas were thought necessary (and in light of the fact that such aid was rarely given to private individuals) indicates that the whites on the island, dégrédados or their descendants though they were, had come to consider themselves a class apart, superior to the blacks who in fact had arrived in São Tomé at virtually the same time and in virtually the same legal and economic position. The reason for the aid, in fact, was to bribe the whites of the island into giving up their economic advantages in order that the prosperity of the island, and thus the return to the King's treasury, would not suffer. The whites, who were a declining percentage of the population, and the forros, would in time find among themselves a community of interest as the São Toméans; they would then combine to secure their common independence from interference by the Crown and efforts by later arrivals to achieve their higher status. However, these liberating orders and these esmollas were to be the last such ones for São Tomé for over two centuries.

Land had now become so valuable (and scarce, due to large grants made to the earliest fazendeiros) that the right of granting it was taken from the donitário and given to the Crown, whose approval was needed for any transfer or sale.[15] If, as seems likely, such a rule was promulgated at the behest of the São Toméans themselves, this may be evidence of the end of the social and economic fluidity that characterized the first years of the settlement, when all were equally poor and suffering under legal disability. The onset of social rigidity, and the corresponding end to the easy availability of land, may be one reason (perhaps more important than the simple question of legal status) why the forros were determined at this time to secure beyond question their rights, particularly the ability to secure property. Alfonso Gil's alleged crime is not known, but it is most likely that it had to do with an effort to exercise his presumed rights as a citizen of São Tomé to acquire land and in general assume the status of a member of the rising 
aristocracy of fazendeiros and slave traders.

Within thirty years, then, of the island's first settlement, a class of people had arisen who had had either slave status or the nearly equally-low status of dégrédado. They had taken advantage of the fluid social and economic situation, São Tomé's distance from the authorities in Lisbon, and the relatively lose control exercised by the donitário (who was mainly interested in making money -- his rule of São Tomé being in reality a kind of investment) to escape from, or emerge from, their subordinate status. The "escape hatch," as it were, was money, specifically the money that could be made from the slave trade and/or from the slave-based growing of sugar. Cash had changed hands: from dégrédado to donitário; from king to fazendéiro; from fazendéiro to trader. And the result was that a class of people who were legally slaves and/or of degraded social status had become free. Indeed, not only were they free, they were on the way to becoming the actual rulers of São Tomé, politically and economically dominant, and not incidentally the procurers and suppliers of a wholly new class of slaves for whom such an acquisition of freedom and opportunity would be closed. Because it was closed, the winning of freedom for this later group would involve violence and bloodshed instead of money.

\section{The First Rebellion}

A contemporary inquest [16] illustrates how some the slaves of São Tomé were being treated. For example, one fazendéiro, Gonzalo Rodriguez, threw them into the sea to drown if they were disobedient. Rodriguez had come to São Tomé in about 1507 and had made his fortune by seizing (in some unnamed manner) the fazendas of three other planters while they were in Kongo on a slave-buying expedition. Rodriguez had his lands confiscated and was expelled from the island for such actions. But if such treatment were common, it obviously was one of the roots of the conflict that produced the decrees on the rights of the forros. It was also one of the reasons for the slave revolt of 1517 , the island's first great social crisis. It was not, as will be seen, the last.

The revolt began on the plantation of one João Lobato on 20 January 1517, and ended after the murder of one white man. [17] Exactly who fought whom is not even clear; one author (citing no source) has called it a war between mulattos (one of whom may have been Lobato) and some blacks. Another (likewise without source) stated that mulattos and blacks together rose and burned the plantation.[18] Whatever the facts, the rising was put down, and a law issued on 15 February 1518 forbidding the freeing of slaves.[19] This strongly suggests that it may have been freed slaves, perhaps forros, who led the uprising. If so, then it is possible that Lobato had refused to recognize the rights of the forros and had tried to return them to, or keep them in, slavery on his plantation.
The situation on the island, of which the rising was a symptom, was critical in terms of the social divisions that were rapidly appearing. Neither the donitário nor his allies among the great fazendeiros recognized that the situation had changed since 1500; that besides slaves and Portuguese (who were far from the elite of metropolitan society themselves) there had grown up a new, purely São Toméan group, mixed in blood and lowly in legal status, but who were not content to remain in a subordinate position forever.

Lobato recovered quickly from that setback. By 1529, he owned twelve of the approximately sixty sugar mills on the island, and had in his possession 169 slaves. [20] His quick recovery is a measure of the economic opportunity that slavery brought to São Tomé in the 16th Century. Besides slaves for his plantation, Lobato reported the shipment to Elmina in 1529 of 2,060 slaves on just three ships; the suffering in such over-crowded conditions can scarcely be imagined. [21] An inquest revealed that in just four months, twelve to fifteen ships commonly left the Kongolese port of Pinda, each carrying 400 to 700 slaves to the island. Other, smaller, ships carried off 200 slaves at a time, but there were still so many slaves on hand that many had to wait in Pinda until sufficient shipping was available. Hundreds died, since conditions in the barracoons of Pinda were as bad as the often-described horrors of the slave-ships. [22] A letter on the trade's abuses from the Captain of São Tomé to the King, written in 1549, blamed the excesses on "the eight or ten principal men of São Tomé."[23]

While these changes and conflicts were occurring, two groups remained separate from the island's dominant class. The first of these were the so-called Angolares, and the second some of the island's slaves; both would play prominent roles in the later attempts to alter or end the slave status of people on São Tomé.

The Angolares (sometimes called Angolars), as their name indicates, were of Angolan origin, probably from the Mbundu ethnic group. Tradition says that they originated as the result of the wreck of a slave ship coming to São Tomé from Angola, which sank after being driven onto the Sété Pedras, a rocky formation about a mile off the south-east coast of the island. [24] The traditional date for the wreck is about 1554. The survivors, of unknown number, reached shore and soon moved into the matos, the unexplored and unsettled southern interior, building a series of small villages called quilombos. [25]

For nearly twenty years, the presence of this group was unknown to the island's other inhabitants, and it is possible that in the early days the Angolares had no idea that there were other people on São Tomé as well. [26] The first contact between the two groups of islanders apparently came from the activities of escaped slaves who fled to the matos and there first encountered the Angolares. Such contact revealed the presence of the Portuguese and their fazendas to the Angolares, and may have been the source of the conflict between Angolar and Portuguese that led to a 
century of intermittent warfare.

But the Angolares, who lived off the natural abundance of the land, had no pressing economic need to invade the northern lands, nor does resentment due to erstwhile enslavement explain the animus shown to the Portuguese; the memory of the original enslavement (which ended disastrously for the slavers on the Sété Pedras) would have been lost after one or two generations. It is therefore likely that it was escaped slaves from the northern fazendas who transmitted to the Angolares their detestation of the slaves' one-time masters. Also, to keep up their numbers, the Angolares took in or captured runaway female slaves, thus making the number of pure or original Angolares quite small within a few years of their arrival on São Tomé. Kidnapping provided only a few new members however, and since the Angolares were otherwise endogamous, their numbers were always small and have remained so to this day.[27] (However, the escaped slaves and the Angolares were not necessarily allies; in the greatest uprising in the island's history, in 1595, the Angolares apparently played no part at all, despite accusations to the contrary).[28]

The first real notice that the settlers had of the Angolares was the latter's sudden descent on the northern lands in 1574. [29] The reasons for the assault remain obscure. Possibly, there was instigation by escaped slaves, and/or the need to replenish a dwindling population by seizing women from the fazendas. After the raid, it became common to refer to anyone living in the matos as an "Angolar" even when the persons in question were Portuguese-speaking runaways from the plantations. [30] But for the most part, the Angolares were left to themselves in the virtually unexplored southern part of São Tomé. [31] The major effect of the Angolares on the island's history was to awaken the settlers to the fact that the interior was not an empty void, but a place of great danger to them.

More important than the Angolares, for all the latter's destructive potential, were the slaves of São Tomé, the human basis for the plantation system that underlay the political and social structure of the island. There were about 9,000-12,000 slaves on the island at mid-century. [32] This number refers only to slaves used as labor on the island itself and does not include those kept there for later shipment to Elmina or to the Americas.

The slaves, on whom the entire society and economy rested, were not, according to contemporary witnesses, [33] mistreated, at least by the standards of the time. Fazendéiros employed only whole families of slaves, rather than separate gangs of unrelated males and females. Though the slave might have been torn from his family in Africa, in São Tomé he was given a woman as his wife and this unit, including all children, was not normally broken up by sale.[34] While there were barracks for slaves, especially toward the end of the 16th Century, it was common in the early years for each slave family to have its own hut on the estate, usually near the cane fields. [35]

\section{Slave Life}

The mulattos who had been freed as a result of the decrees of 1515 and 1517 were, in their manner of living, similar to the rapidly declining number of white inhabitants. These so-called Filhos da Terra ("Children of the Land") were often among the wealthiest and most powerful of the inhabitants of São Tomé, possessing hundreds of slaves and other retainers.[36] Others, though nominally still slaves, were said to have not been in a state of slavery but in "servitude," akin to the serfdom of medieval Europe. Though owing labor to the fazendéiro, they largely led their own lives; if conditions became too onerous they could always flee to the matos to live much as before but without the debt of labor on the plantation. [37] Since it was easy to escape to and live in the matos, any really harsh treatment would have led to slaves' wholesale desertion, which did not in fact occur until after the decline in the island's sugar industry towards the end of the 16th Century.

There is evidence that the life of the slave at that time did become much more onerous, possibly as a result of the fazendeiros' need to squeeze every bit of labor out of the slaves in order to compete with the flood of sugar from Brazil. In contrast to the accounts of mid-century, there were references to slaves being forced to live in locked houses on the estate and to their being treated "worse than cattle."[38] Further, slaves, now confined to the plantations, were often not even allowed to cultivate their own fields.[39] Though this may have entailed more expense for the fazendéiro in providing for the slaves, it allowed firmer control over them and no more need to permit days off to work their own patches of ground. The breaking up of slave families, the forced breeding of slaves "like horses," and the refusal to free slaves' children (which had occasionally occurred) became the norm.[40] Thus, whatever the lot of slaves in the high noon of São Tomé's history, by the late 1500 s their state had indeed become indistinguishable from that of the slaves of the Americas, with no pretense of mere "servitude."[41] In these circumstances, it is easier to understand the great slave revolt of 1595 and why this movement swept the fazendas of São Tomé like a storm.

Fearing just such a situation, the islanders had secured royal decrees dated 13 September and 6 December 1574 creating a permanent militia, which was at first charged with fighting the Angolares. The principal component of the force was newly-arrived dégrédados, who had their term of degradation reduced by five years in return for their service. [42] São Tomé had recovered quickly from the 1574 Angolar raid, quickly enough for the rebuilt main town to burn down due to an accidental fire in 1585. [43] But physical recovery did not cure the social and psychological injury; in the aftermath of the Angolar attack, the island's wealthiest and most economically-skilled inhabitants began to leave for Brazil. With such a loss of 
stability -- essentially exchanging the island's richest inhabitants for more dégrédados -- and the increasingly harsh regimen imposed on the plantation slaves, new eruptions were bound to occur. The worst of these was the upheaval known as the "rising of Amador," in the summer of 1595 .

\section{The Second Rebellion}

The rebellion took its name from its nominal leader, Amador, variously described as an escaped or as a "revolted" slave, and it was the largest attempted revolution that São Tomé was ever to know. Its roots include the growing exploitation of the island's slaves, the fact that communities of escaped slaves existed in the matos, the example set by assaults of both previous escapees and the Angolares, and finally the grave political and social divisions within the society which made any united effort to suppress the menace beforehand almost impossible.

To contemporaries, the revolt was not just a matter of rebellious slaves, but also seen as a racial war. The horror of, and anger at, the events of July and August 1595 is apparent in every narrative of the event. [44] Murders of "white men" took place everywhere, even in churches. Many plantations were burned, and the desperate officials freed all criminals, and released "sinners" from excommunication, if they would join the forces fighting the rebels. When pitched battles occurred, no quarter was given and all weapons, from clubs to artillery, were freely employed. Prisoners were commonly hanged. In the end, Amador was betrayed by some of his followers: captured, hanged, drawn and quartered, his heart was put on public display. Other captured leaders were mutilated before hanging. During the rebellion, three-fourths of the sugar mills on the island went up in flames. [45]

The cost of the war was 1,500 cruzádos $(600 \$ 000$ escudos). [46] The worst losses, however, were human ones. Most well-off São Toméans were already leaving for Brazil. If the claim that the rebel army numbered some 5,000 men is reliable, and that the loyalists' force, consisting of all the men of the island, was slightly smaller (perhaps about 4,500) it would indicate that the total "white" (actually, free mulatto) population in the mid-1590s was about 20,000, not a very large figure, and an indication that population decline had already begun. The exodus to Brazil, noted as early as 1580 , was greatly accelerated by Amador's revolt. The great fazendeiros, especially, seeing their slaves taking up arms with the avowed intention to kill every "white" man, must have felt the lure of Brazil irresistible. [47]

The defeat of Amador did not end the war. Some of his men did not surrender and they continued to harass the northern flatlands, as escaped slaves had done for years.
Angolar raids also continued, especially against the outer, more southerly, fazendas. As late as 1598 , it was noted that the war was continuing "with all vigor." In fact, another revolt occurred in 1616, and it too degenerated into a racial conflict.

This revolt of "blacks" (pretos) occurred in the southwest of the island, and it took two companies of militia to put it down. The rebels were noted as being crioulas negras ("dark creoles") and that upon their rebellion, the whites (brancos) fled to the island's Fort San Sebastian. [48] The "whites" could not have been very many if all of them could fit into the little fort during the crisis. With only a dozen real soldiers on the island, and most of the "whites" cowering in the fort, it is likely that the militia that put down the revolt was made up mostly of armed slaves, an expedient used to repel a Dutch assault in 1599. Many São Toméans had slave retainers, and in the unsettled state of the island, it is likely that their equipment include arms, a dangerous and desperate action, considering the conditions on São Tomé.

\section{Conclusions}

What was the ultimate result of these rebellions? Many slaves became free, if only by fleeing to the matos and either forming separate ex-slave communities (as happened among the "maroons" on many West Indian islands or on the South American mainland, most notable in Brazil and the island of Jamaica) or else by joining one of the Angolar quilombos (rural villages). For those who did not or could not flee, the result was continued enslavement under more rigorous conditions than ever before. The decline of the island's sugar industry (both caused by, and a result of, the collapse of its plantations, and the economic triumph of Brazil) did not ameliorate the conditions of the slaves, even though they had essentially lost their economic raison d'être. It was also not a question of collecting or holding slaves for shipment to the Americas; by the early 1600 s, most slaves went directly from Africa to Brazil.

Then why continue to hold slaves, who provided little income and represented a constant threat of rebellion? Perhaps sheer social inertia; slavery was the basis of São Toméan society; that it had lost its economic rationale was irrelevant. Also, there was the fear, common in most slave-based societies, that freeing slaves or even ameliorating their condition would lead to a loss of status at best and a race war at worst. Under those circumstances, slavery continued on São Tomé until the early 19th century, for no particular reason. The slaves who had bought their freedom in the early 16th century remained free. Those who had bolted for the matos remained free. For the rest, there was bloody, futile, rebellion or a lingering, archaic captivity, even in the presence of those whose ancestors had escaped such a fate. 


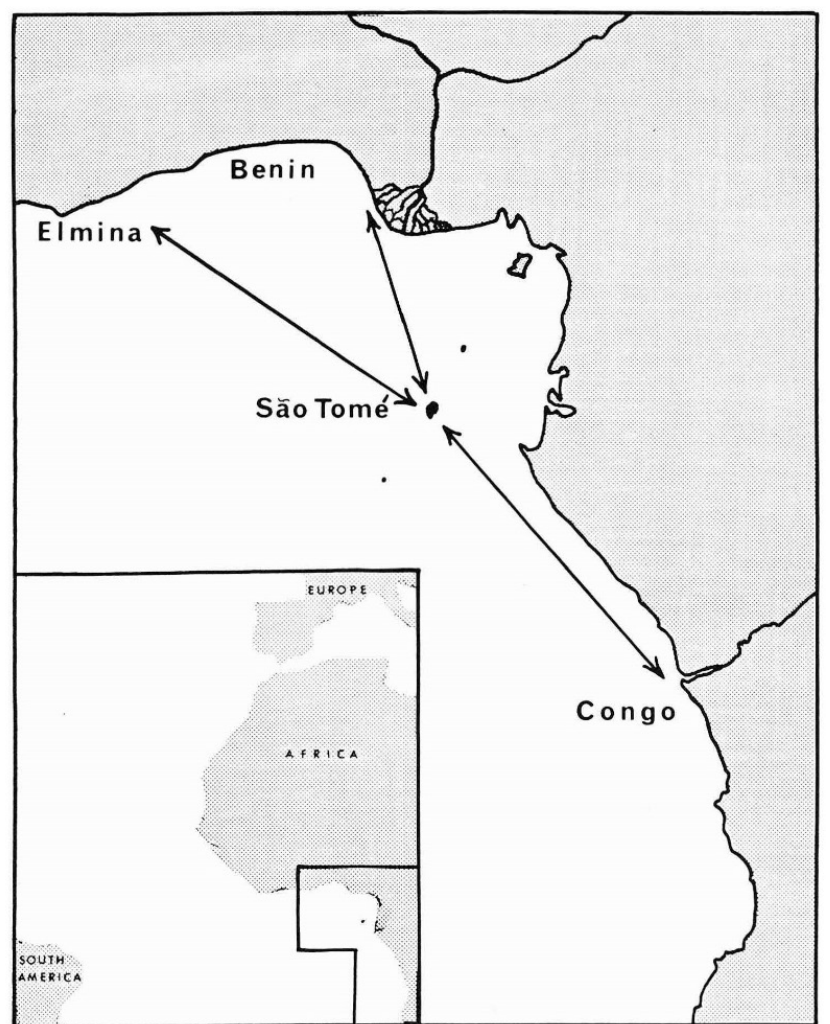

Figure 1. Map showing the location of São Tomé in relation to the African coast and within the Gulf of Guinea

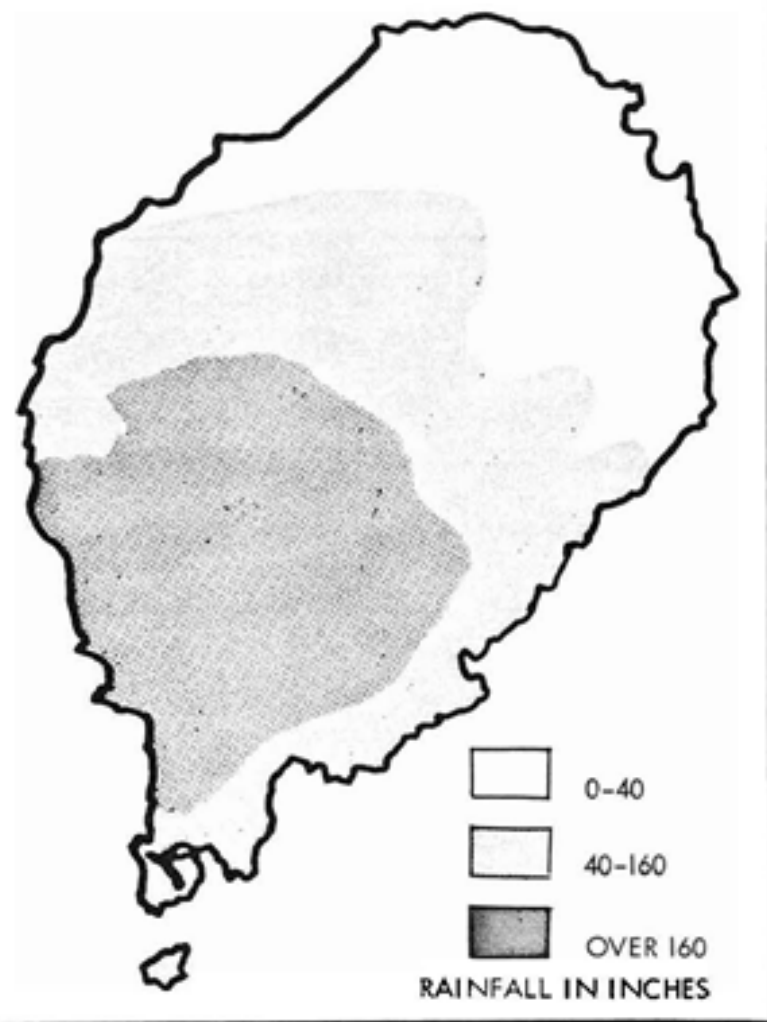

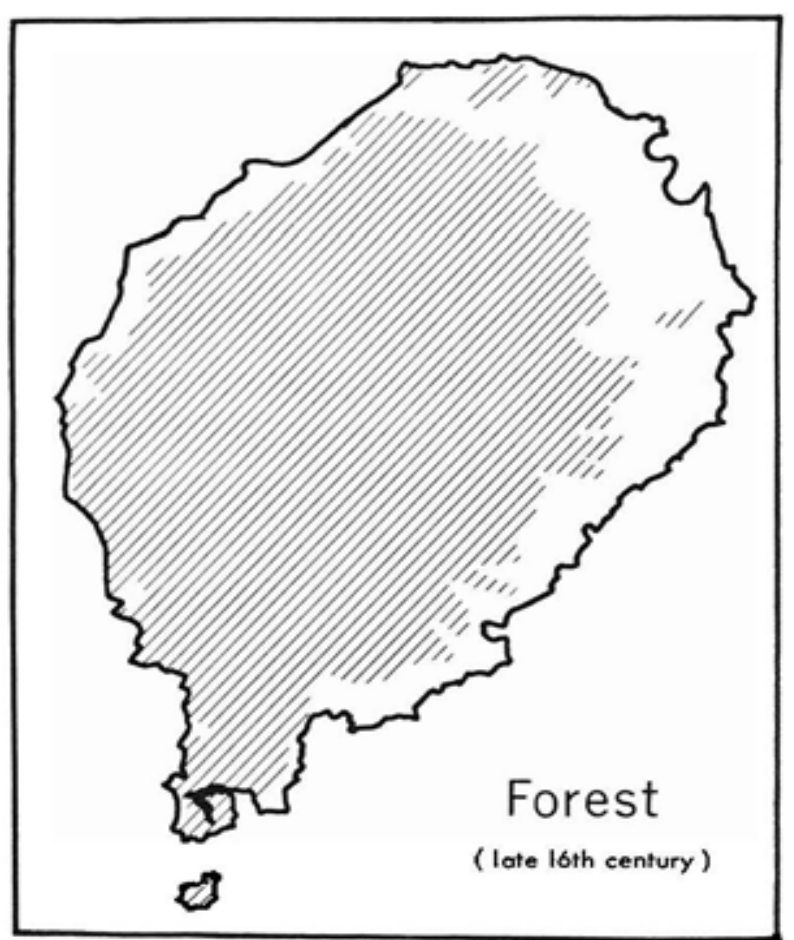

Figures 2, 3. Maps showing rainfall pattern, and location of the "matos" [uncleared rainforest] on São Tomé.

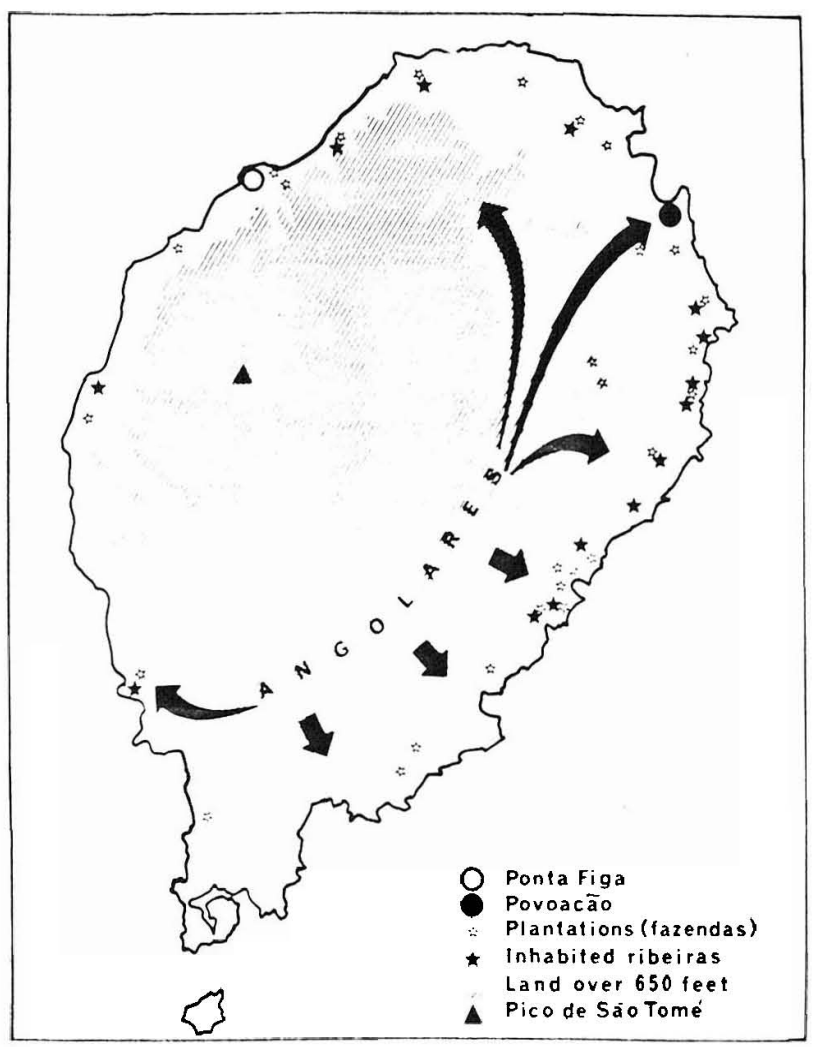

Figure 4. Map of São Tomé, showing locations of Ponta Figa [the original settlement], the Povoaçao [the city/main settlement, the "matos" [uncleared rainforest], "ribeiras," [short streams used to power sugar mills,], the main plantations ["fazendas], and the position of the main Angolar "quilombos" and the routes taken by the Angolars during their attacks on the Povoaçao and the sugar plantations. [49] 


\section{REFERENCES}

[1] cf. Raymundo Jose de Cunha Mattos, Corografia Historica da Ilha de S. Tomé, Pórto: Typografia da Revista, 1842, p. 1; Jose Joaquim Lopes de Lima, Ensaio Sobre a Statistica das Possessões Pórtugueses, vol. 2; Lisbon: Imprensa Nacional, 1844, p. VII.

[2] cf. Francisco Tenreiro, A Ilha de S. Tomé. Lisbon: Junta de Investigações do Ultramar, 1961; pp. 57-58. Armando Cortesão, Descobrimento e Cartografica das Ilhas de S. Tomé e Príncipe, Lisbon: Junta de Investigações do Ultramar, 1971.

[3] cf. Francisco Tenreiro, Cabo Verde e S. Tomé: esquema de uma evolução conjunto, Praia (Cape Verde Is.): Imprensa Nacional, 1956, passim; Virginia Rau and Jorge de Macedo, O Açucar na Ilha da Madeira: analise de um calculo de produção dos fims do século VX; Congresso Internacional de Historia dos Descobrimentos, Lisbon, 1961, vol. 5.

[4] Archivo da Torre de Tombo, Livro das Ilhas, fl. 20v, 2 Sept. 1493.

[5] Jose Lucio de Azevedo, Historia dos Cristãos Novos Pórtuguesas, Lisbon: Livraria Classica, 1921, p. 21.

[6] Cunha Mattos, Corografia, p. 3; Vicente D'Eca, Normas Economicas nas Colonias Pórtuguesas até 1808, Coimbra: Coimbra University Press, 1921, pp. 37-38; C. R. Boxer, Race Relations in the Portuguese Empire, 1415-1825, Oxford: Clarendon Press, 1963, p. 15; Th. Monod, et. al., eds., "Valentim Fernandez 'Descrição da Costa Occidental d'Africa,' 'Centro dos Estudos da Guine Pórtuguesa, Boletim, \#15 (1951), p. 121.

[7] ATT, Livro das Ilhas, fl. 106, 21 Nov. 1493.

[8] Ibid., f1. 59v., 11 Dec. 1499; R. J. Cuhna Mattos, Compendio Historico das Possessões de Portugal na Africa, n.p., 1963, p.101.

[9] Ibid., fl. 60v. 15 Dec. 1499 (two documents).

[10] Fernandez, op. cit., passim.

[11] Ibid., p. 121.

[12] Ibid., p. 121.

[13] ATT, Livro das Ilhas, fl. 199, 29 Jan. 1515.

[14] Ibid., fl. 203, 24 Jan. 1517.

[15] Ibid., fl. 161v. 3 Nov. 1516.

[16] Biblioteca Nacional de Ajuda, cota 111-4-98, 11 Dec. 1511, 15 Jan. 1512.

[17] Archivio Vaticano, Archivio della Nunziatore di Lisbona, Apóntamentos Historicos, fl. 1v.

[18] Cunha Mattos, Corografia, p. 4.

[19] Ibid., p. 102.

[20] ATT, CC, 1-42-90, 13 March 1529.

[21] Ibid.
[22] ATT, $C C, 1-80-105,12$ Nov. 1548. For a description of slave-ships and conditions on board of them cf. Basil Davidson, The African Slave Trade, New York: Atlantic-Little, Brown, 1961, p. 149.

[23] ATT, CC, 1-82-156, 18 Feb. 1549.

[24] F. Tenreiro, A Ilha, p. 63.

[25] Ibid., pp. 63, 72.

[26] Antonio Almeida, "Contribução para o Estudo da Antropólogia dos Angolares," Actas da VI Conferencia dos Africanistas Occidentais, p. 19.

[27] By the end of the 16th Century, any black found in the forests of São Tomé was called an "Angolar." The Portuguese did not draw subtle ethnic or historical distinctions among non-slave blacks, and "Angolar" became and remains a generic term for São Toméans.

[28] A. Almeida, "Da Origem dos Angolares -- habitantes da Ilha de S. Tomé," Memórias da Academia das Ciencias, v. 8, 1964, p. 288; Almeida “Contribução,” p. 23. A 1950 census gave an Angolar adult population of 2,290, and their numbers in the past cannot have been much greater.

[29] Ibid., pp. 72-73.

[30] F. Tenreiro, "A Floresta e a Occupação Humana na Ilha de S. Tomé," Garcia da Orta, vol. 9, no. 4, 1961, p. 653.

[31] F. Tenreiro, "Descrição da Ilha de S. Tomé," Garcia da Orta, vol. 1, \#1, 1953, p. 224.

[32] Anon., Viagem de Lisboa a Ilha de S. Tomé, Lisbon: Pórtugalia Editoria, n.d., passim; V. Fernandez, op. cit.

[33] F. Tenreiro, "S. Tomé, um exemplo da Organização do Espaço," Estudios de Ciencias Póliticas e Sociais, no. 51, 1961, p. 72.

[34] Anon., Viagem, pp. 61-62.

[35] Ibid., pp. 51-52, 78.

[36] F. Tenreiro, "Exemplo,” p. 72.

[37] J. Cuvalier \& L. Jadin, L'Ancien Congo d'Apres les Archives Romains, pp. 54-55.

[38] Ibid., p. 153

[39] Le Blanc, Sieur Vincent, Les Voyages Fameux de Sieur Le Blanc, Paris: Coulon Editoria, 1848, p. 148. The original report was written about 1580 .

[40] F. Tenreiro, "Aspectos da colonização da Ilha de S. Tomé, séculos 16-20, C. R. XII Congresso Luso-Espanol para o Progresso das Ciencias, v. 6, 1950, p. 162.

[41] R. J. Cunha Mattos, Compendio Historico das Possessões de Portugal na Africa, Rio de Janeiro: n.p., 1962, p. 104.

[42] Ibid., p. 104-105.

[43] Cunha Mattos, Corografia; \& Lopes de Lima, Ensaio, passim.

[44] Manuel do Rosario Pinto, Historia da Ilha de S. Tomé, Lisbon: Ineditos Coloniais, series B, no. 1, 1937 (orig. 1737), passim. 
[45] Arquivo Historico Ultramarino, São Tomé, caixa 1, 16 Mar 1598.

[46] Ibid., doc. 59b, 20 Feb. 1617. It is difficult to calculate the actual value of $16^{\text {th }}$ Century money. Before the Portuguese adoption of the Euro, a Portuguese escudo, designated by the \$ symbol, was worth 35 to the U.S. dollar. Thus, the costs of the revolt, $600 \$ 000$ would be equal to a modern $\$ 17$ U.S. dollars, an absurdly small sum, given that the $\$$ sign served as a decimal point. Whatever the actual or nominal costs of the rebellion, it was clearly a huge financial burden on the declining island economy.

[47] Luciano Cordeiro, Memorias do Ultramar; viagems, explorações e conquistas, Lisbon: Imprensa Nacional, 1881, ch. 4, p. 27. This information supposedly came from one Garcia Mendes Castello Branco, who lived on São Tomé in the early 17 th Century.

[48] AHU, São Tomé, caixa 1, 16 Mar. 1598.

[49] All maps were drawn by the author and Dr. Charles W. Berberich, formerly of Southern Illinois University.

\section{Bibliography}

Archivo Nacional da Torre de Tombo, Lisbon, Corpo Cronologico, Part I, maços 2, 19, 21 42, 80, 82.

Archivo Nacional da Torre de Tombo, Lisbon, Corpo Cronologico, Part II, maços, 22, 204, 246.

Archivo Nacional da Torre de Tombo, Lisbon, Corpo Cronologico, Part III, maços, 4, 17.

Archivo Nacional da Torre de Tombo, Lisbon, Livro das Ilhas.

Archivo Historico Ultramarino, Lisbon, São Tomé, caixas 1-7.

Biblioteca Nacional de Ajuda, Lisbon, cotas, 44-XIV-4, 51-V-6, 51-VIII-7, 51-VIII-44, 51-VIII-25.

Archivo Vaticano, Rome (Vatican City), Nunziatura di Portogallo, vols. 14, 21, 22, 26.

Archivo Vaticano, Rome (Vatican City), Archivo della Nunziature di Lisbona, vols. 30, 54, 72.

Anonymous, Viagem de Lisboa á Ilha de S. Tomé, Lisbon: Portugalia Editoria, n.d.

Azevedo, Jose Lucio de, Historia dos Christãos Novos Portuguesas, Lisbon: Livraria Classica, 1921.

Cordeiro, Luciano, ed., Memorias do Ultramar; viagens, explorações, e conquistas, Lisbon: Imprensa Nacional, 1881.

Cunha Mattos, Raymundo Jose da, Compendio Historia das Possessões de Portugal na Africa, Rio de Janeiro: n.p., 1962 (orig. 19th cent.)

Cunha Mattos, Raymundo Jose da, Corografia Historica das llhas de S. Tomé, Príncipe, Annobom e Fernão do Pó, Porto, Portugal: Typografia da Revista, 1841.

Davidson, Basil, The African Slave Trade, New York: Atlantic-Little, Brown, 1961.
D’Eca, Vicente, Normas Economicas nas Colonias Portuguesas até 1808, Coimbra, Portugal: Imprensa Universitaria de Coimbra, 1921.

Deere, Noel, The History of Sugar, London: Chapman and Hall, Ltd., 1949.

Garfield, Robert, A History of São Tomé Island: the key to Guinea, 1470-1655, Lewiston, New York: Edwin Mellen Press, 1992.

Le Blanc, Sieur Vincent, Les Voyages Fameux de Sieur Le Blanc, Paris: Coulon Editoria, 1848.

Lopes de Lima, José Joaquim, Ensaio sobre a Statistica das Possessões Portuguesas, vol. 2, Lisbon: Imprensa Nacional, 1844.

Rosario Pinto, Padre Manuel de, Historia da llha de S. Tomé, Lisbon: Ineditos Coloniais, ser. B, no. 1, 1937 (orig. 1732).

Silveira, Luis, Iconografia das Cidades Portuguesas do Ultramar, v. 2, Lisbon: Ministeiro do Ultramar, n.d.

Tavares, Maria Jose Piment Ferro, Os Judeos em Portugal no Século $X V$, Lisbon: Universidade Nova de Lisboa, 1892.

Tenreiro, Francisco, A Ilha de S. Tome, Lisbon: Junta das Investigações do Ultramar, 1961.

Almeida, Antonio de, "Contribução para o Estudio da Antropologia dos Angolares," Actas da VI Conferencia dos Africanistas Ocidentais, fol. 5, 1956.

Barata, Oscar, "O povamento de Cabo Verde, Guine e São Tomé," Curso Extensão Universitaria, Instituto Superior de Ciencias Sociais e Politica Ultramarina, 1966.

A. Almeida, "Da Origem dos Angolares--habitantes da Ilha de S. Tomé," Memorias da Academia das Ciencias, Lisbon, vol. 8, 1964.

Cuvelier, J., and Jadin, Louis, "L'Ancien Congo d'apres des archives Romains," Memoires du Institut Royal Colonial Belge; section das sciences morales et politique, vol. 36, 1954.

Garcia, Carlos Alberto, "A Ilha de S. Tomé como centro experimental do comportamento dos Lusos nos Tropicos," Studia, no. 19, December 1966.

Monod, T., et. al., eds., "Valentim Fernandez, 'Descrição da Costa Occidental d'Africa'," Boletim do Centro dos Estudios do Guine Portuguesa, no. 15, 1951.

Tenreiro, Francisco, "A Floresta e a Occupação Humana na Ilha de S. Tomé," Garcia da Orta, vol. 9, no. 4, 1961.

F. Tenreiro, "Aspectos da colonização da Ilha de S. Tomé, séculos 16-20," Actas da XII Congresso Luso-Espanhol para o Progresso das Ciencias, vol. 6, 1950.

F. Tenreiro, "Descrição da Ilha de S. Tomé no século XVI," Garcia de Orta, vol. 1, no. 2, 1953.

F. Tenreiro, "S. Tomé, um exemplo da organização do espaço," Estudios de Ciéncias Politicas e Sociasis, no. 51, 1961.

Soeiro de Brito, Raquel, "Guiné, Cabo Verde e São Tomé e Príncipe: alguns aspectos da terra e dos homens," Curso Extensão Universitaria, Instituto Superior de Ciéncias Sociais e Politica Ultramarina, 1966. 